\title{
Description of Cellulophaga algicola sp. nov., isolated from the surfaces of Antarctic algae, and reclassification of Cytophaga uliginosa (ZoBell and Upham 1944) Reichenbach 1989 as Cellulophaga uliginosa comb. nov.
}

John P. Bowman

Tel: +613 62262776. Fax: +613 62262642.e-mail: john.bowman@utas.edu.au

School of Agricultural Science, University of Tasmania, GPO Box 252-54 Hobart, Tasmania 7001, Australia

\begin{abstract}
A group of strains with potent extracellular enzymic activity were isolated from the surfaces of the chain-forming sea-ice diatom Melosira and from an unidentified macrophyte collected from the Eastern Antarctic coastal zone. 16S rDNA sequence analysis indicated that the strains belonged to the genus Cellulophaga and showed greatest similarity to the species Cellulophaga baltica (sequence similarity $97 \%$ ). Phenotypic characteristics, DNA base composition and DNA-DNA hybridization values clearly separate the Antarctic strains from Cellulophaga baltica and other Cellulophaga species. Thus, the strains form a distinct and novel species and have the proposed name Cellulophaga algicola sp. nov. (type strain IC166 ${ }^{\top}=$ ACAM $630^{\top}$ ). In addition, it was recognized that the species Cytophaga uliginosa (ZoBell and Upham 1944) Reichenbach 1989, a species phylogenetically remote from the type species of the genus Cytophaga, possessed 165 rDNA sequences and phenotypic and chemotaxonomic traits similar to those of other Cellulophaga species. Thus, it was proposed that the species Cytophaga uliginosa be renamed as Cellulophaga uliginosa comb. nov.
\end{abstract}

Keywords: Cellulophaga, Antarctica, epiphytic bacteria, agarolytic bacteria, Cytophaga

\section{INTRODUCTION}

Dense algal assemblages within Antarctic sea ice are a haven for a rich diversity of bacteria including many psychrophilic taxa (Bowman et al., 1997b). Many of these ice-dwelling (sympagic) bacteria belong to the family Flavobacteriaceae (order Cytophagales). Recent fluorescent in situ hybridization studies suggest that the order Cytophagales can be highly abundant in the coastal pelagic zone of Antarctica, contributing from 20 to $70 \%$ of the bacterial biomass in various seawater samples (Glöckner et al., 1999). Owing to this group's large biomass, they conceivably have important roles in secondary mineralization processes, in which organic material formed by primary production (mostly photosynthetic activity) is degraded back into micronutrients.

Species belonging to the family Flavobacteriaceae that

Abbreviation: CMC, carboxymethylcellulose. have been isolated from Antarctic marine and marinederived ecosystems include Gelidibacter algens, Psychroserpens burtonensis (Bowman et al., 1997a), Psychroflexus torquis (Bowman et al., 1998), Polaribacter irgensii, Polaribacter filamentus, Polaribacter glomeratus, Polaribacter franzmannii (Gosink et al., 1998), a variety of Flavobacterium spp. (McCammon et al., 1998; McCammon \& Bowman, 2000) and several other unclassified isolates (Bowman et al., 1997b). Some of these species are sympagic and pelagic algal epiphytes (J. P. Bowman, unpublished data), while others are planktonic, some of which can form gas vesicles (Gosink et al., 1998). A group of agarolytic Antarctic strains, isolated from masses of the chainforming pennate diatom Melosira (colonizing the lower surface of some areas of coastal sea ice) and from the surfaces of an unidentified macrophyte, were also found to belong to the family Flavobacteriaceae (Bowman et al., 1997b). The strains were most similar to the recently described genus Cellulophaga (Johansen et al., 1999), isolated from the surfaces of the seaweed 
Fucus serratus growing in the Baltic Sea. The goal of this study was to determine the taxonomy of the Antarctic agarolytic isolates in relation to the genus Cellulophaga and to other species with similar $16 \mathrm{~S}$ rDNA sequences.

\section{METHODS}

Strains and cultivation conditions. The Antarctic agarolytic strains were isolated from strips of ice algal and macrophytic material $(1-2 \times 3-5 \mathrm{~cm})$. The material was cut with sterile scalpels and placed flat upon the surface of marine 2216 agar (Difco) and incubated at $0-4{ }^{\circ} \mathrm{C}$. The appearance of paleorange spreading growth from the algal strips onto the agar was noticeable after 2-3 weeks. Cells from the spreading growth were then transferred to marine 2216 agar and incubated at $10^{\circ} \mathrm{C}$. The resultant colonies were selected for further purification. Isolates and reference strains investigated in this study are shown in Table 1. All strains used in the study were routinely cultivated on marine 2216 agar at $20{ }^{\circ} \mathrm{C}$.

Phenotypic characterization. Most phenotypic tests have been published previously (Bowman et al., 1997a). Gliding motility tests were performed by preparing a light suspension of cells in seawater and then placing a drop on quarterstrength marine 2216 medium solidified with $1 \%$ agarose. After $16 \mathrm{~h}$ incubation at $10^{\circ} \mathrm{C}$, the inoculated area was covered with a glass coverslip and examined by oil-immersion phase-contrast microscopy. Flexirubin pigments were detected by suspending cells in $20 \% \mathrm{KOH}$ (Fautz \& Reichenbach, 1980). Carboxymethylcellulose (CMC), fibrinogen and elastin hydrolysis were tested by overlaying marine 2216 agar with a thin layer of $0.5 \%$ CMC, $0.2 \%$ fibrinogen or $0.2 \%$ elastin in seawater solidified with $1.2 \%$ agar and observing for hydrolysis zones after $14-21 \mathrm{~d}$ incubation at $20^{\circ} \mathrm{C}$. Lipase activity was tested with the procedure of Kouker \& Jaeger (1987), using marine 2216 plates containing $1 \mathrm{mg}$ rhodamine $\mathrm{B} \mathrm{ml}^{-1}$ and $2 \cdot 5 \%(\mathrm{w} / \mathrm{v})$ olive oil (Sigma; both filtered-sterilized). Plates were incubated for $7 \mathrm{~d}$ at $20{ }^{\circ} \mathrm{C}$ and observed under long wavelength $(\sim 350 \mathrm{~nm})$ UV light. Production of acid from carbohydrates (at $0.5 \% \mathrm{w} / \mathrm{v}$ ) was examined in liquid medium with $5 \mathrm{ml}$ oxidation/fermentation medium (Leifson, 1963) aliquotted into $10 \mathrm{ml}$ screw-cap test tubes and incubated for $14-21 \mathrm{~d}$ at $20^{\circ} \mathrm{C}$

DNA base composition. DNA was extracted by the procedure of Marmur \& Doty (1962) and the DNA G + C content was determined from thermal denaturation profiles (Sly et al., 1986).

DNA-DNA hybridization. The spectrophotometric renaturation rate kinetic procedure adapted by Huss et al. (1983) was used to determine DNA-DNA reassociation values between genomic DNA of different strains. Genomic DNA was sheared to a mean size of $1 \mathrm{~kb}$ by sonication, dialysed overnight at $4{ }^{\circ} \mathrm{C}$ in $2 \times$ SSC buffer $(0.3 \mathrm{M} \mathrm{NaCl}, 0.03 \mathrm{M}$ sodium citrate, $\mathrm{pH} 7 \cdot 0$ ) and adjusted in concentration to approximately $75 \mu \mathrm{g} \mathrm{m} \mathrm{m}^{-1}$. Following denaturation of the DNA samples, hybridization was performed at the optimal temperature for renaturation $\left(T_{\mathrm{OR}}\right)$, which was $25^{\circ} \mathrm{C}$ below the DNA melting temperature and was calculated from the following equation: $T_{\mathrm{OR}}=48 \cdot 5+(0 \cdot 41 \times \% \mathrm{G}+\mathrm{C})$, where $T_{\text {or }}$ is in ${ }^{\circ} \mathrm{C}$ and $\% \mathrm{G}+\mathrm{C}$ is the $\mathrm{mol} \% \mathrm{G}+\mathrm{C}$ content. The declines in absorbance over a $60 \mathrm{~min}$ interval of DNA mixtures and control DNA samples were used to calculate DNA hybridization values from the following equation (Huss et al., 1983):

DNA hybridization $(\%)=100(4 \mathrm{AB}-\mathrm{A}-\mathrm{B} / 2 \sqrt{ }(\mathrm{A} \times \mathrm{B}))$

where $\mathrm{A}$ and $\mathrm{B}$ represent the change in absorbance for the two DNA samples being compared and $\mathrm{AB}$ represents the change in absorbance for equimolar mixtures of $\mathrm{A}$ and $\mathrm{B}$. A DNA hybridization value equal to or below $25 \%$ is considered to represent background hybridization and is thus not considered significant.

Table 1. Bacterial strains used in this study

\begin{tabular}{|c|c|c|}
\hline Taxon & Strain* & Isolation site \\
\hline \multicolumn{3}{|l|}{ Antarctic strains } \\
\hline Agarolytic Cytophaga-like sp. & $\mathrm{IC} 166^{\mathrm{T}}=\mathrm{ACAM} 630^{\mathrm{T}}$ & Melosira sp., sea ice \\
\hline Agarolytic Cytophaga-like sp. & $\mathrm{IC} 155=$ ACAM 631 & Melosira sp., sea ice \\
\hline Agarolytic Cytophaga-like sp. & $\mathrm{IC} 156=\mathrm{ACAM} 632$ & Macrophyte \\
\hline Agarolytic Cytophaga-like sp. & $\mathrm{IC} 167=\mathrm{ACAM} 633$ & Macrophyte \\
\hline Agarolytic Cytophaga-like sp. & $\mathrm{IC} 137=\mathrm{ACAM} 634$ & Melosira sp., sea ice \\
\hline Agarolytic Cytophaga-like sp. & IC135 & Melosira sp., sea ice \\
\hline Agarolytic Cytophaga-like sp. & IC136 & Melosira sp., sea ice \\
\hline \multicolumn{3}{|l|}{ Reference strains } \\
\hline Cellulophaga lytica & ACAM $74^{\mathrm{T}}=$ ATCC $23178^{\mathrm{T}}$ & Surface sediment \\
\hline Cellulophaga lytica & NCIMB 1388 & Seawater aquarium outflow \\
\hline Cellulophaga lytica & NCIMB 1395 & Seawater aquarium outflow \\
\hline Cellulophaga lytica & NCIMB 1412 & Surface sediment \\
\hline Cellulophaga baltica & LMG $18535^{\mathrm{T}}$ & Surface of seaweed (Fucus serratus), Baltic Sea \\
\hline Cellulophaga fucicola & LMG $18536^{\mathrm{T}}$ & Surface of seaweed (Fucus serratus), Baltic Sea \\
\hline Cytophaga uliginosa & ACAM $538^{\mathrm{T}}=$ ATCC $14397^{\mathrm{T}}$ & Surface sediment \\
\hline Cytophaga marinoflava & ACAM $75^{\mathrm{T}}=\mathrm{LMG} 1345^{\mathrm{T}}=\mathrm{ATCC} 19326^{\mathrm{T}}$ & Seawater aquarium outflow \\
\hline Cytophaga latercula & ATCC $23177^{\mathrm{T}}$ & Seawater aquarium outflow \\
\hline
\end{tabular}

* Abbreviations: ACAM, Australian Collection of Antarctic Microorganisms, University of Tasmania, Hobart, Tasmania, Australia; NCIMB, National Collection of Industrial and Marine Bacteria, Aberdeen, UK. 
Fatty acid analysis. Strains were cultivated in marine 2216 broth at $20^{\circ} \mathrm{C}$, harvested and then lyophilized using a vacuum freeze-drier (Dynavac). Whole-cell fatty acid profiles were determined quantitatively by gas chromatography-mass spectrometry (GC-MS) and the geometry and position of double bonds in monounsaturated fatty acids were confirmed using dimethyldisulfide derivatization and analysis by GC-MS as described by Nichols et al. (1986). The double-bond positions are numbered from the methyl $(\omega)$ end of the fatty acid.

16S rDNA sequence analysis. The $16 \mathrm{~S}$ rDNA sequence for a representative agarolytic strain $\left(\mathrm{IC} 166^{\mathrm{T}}\right.$ ) was obtained in an earlier study (Bowman et al., 1997b). The sequence was compared with the compilation of $16 \mathrm{~S}$ rDNA sequences available in the GenBank nucleotide library and aligned to sequences of the members of the family Flavobacteriaceae. Near-complete sequences (1420-1500 bp) were aligned with hypervariable regions aligned according to secondary structural features (Gutell, 1994). Analyses of the 16S rDNA datasets utilized PHYLIP (version 3.57c) (Felsenstein, 1993). DNADIST was used to determine sequence similarities using the maximum-likelihood algorithm option. Phylogenetic trees were constructed with the neighbour-joining method by using the program NEIGHBOR. Bootstrap analysis was performed with SEQBOOT and CONSENSE using 250 resamplings of the dataset, utilizing both DNADIST and NEIGHBOR as well as the program DNAPARS, which constructs trees based on the maximum-parsimony method.

\section{RESULTS AND DISCUSSION}

\section{Morphological and phenotypic properties of the Antarctic strains}

When cultivated on marine 2216 agar $\left(2 \mathrm{~d}, 20^{\circ} \mathrm{C}\right)$, the Antarctic strains initially formed yellow-orange pigmented, flat, irregular to circular colonies with a butyrous consistency and with diameters of 1-3 $\mathrm{mm}$. The colony edges were much paler in pigmentation than the central mass and were very irregular. The colonies were slightly sunken into the agar, which had softened but not liquefied. Flooding of the agar with a $1 \%(\mathrm{w} / \mathrm{v})$ KI-sublimed iodine (1:1) solution highlighted extensive clearing zones around the growth, indicating that the agar had been at least partially depolymerized and degraded. The $\mathrm{KOH}$ test results indicated that flexirubin pigments were absent. Microscopic investigations revealed that the strains appeared rod-like, with either rounded or tapered ends and with cell lengths and widths ranging from 1.5 to 4 and 0.4 to $0.5 \mu \mathrm{m}$, respectively. All strains examined exhibited rapid gliding motility.

The Antarctic strains grew profusely on a variety of complex seawater agars including marine 2216 agar, R2A (Oxoid) and Anacker-Ordal agar (Bernardet et al., 1996) supplemented with $35 \mathrm{~g}$ seawater salts $1^{-1}$. Some strains were able to grow poorly on nutrient agar. No growth occurred on R2A or Anacker-Ordal agar without added $\mathrm{NaCl}$. The temperature range for growth was between -2 and $28^{\circ} \mathrm{C}$. The optimal temperature for growth was about $15-20^{\circ} \mathrm{C}$ on solid media and was slightly higher $\left(20-25^{\circ} \mathrm{C}\right)$ in liquid media. Biochemical test results for the strains are compared with other Cellulophaga species in Table 2 and are also given in the species description below.

\section{Fatty acid profiles}

The fatty acid profile of $\mathrm{IC} 166^{\mathrm{T}}$ (the hypothetical median representative of the Antarctic isolates) has been reported previously along with fatty acid profiles for the species Cellulophaga lytica and Cytophaga uliginosa (Bowman et al., 1998). Additional strains were analysed in this study in order to confirm the homogeneity of the species groups. Fatty acid data for each Cellulophaga species were quite similar and are shown in Table 3 . The fatty acids $a 15: 1 \omega 10 \mathrm{c}, i 15: 0$, $a 15: 0,16: 1 \omega 7 \mathrm{c}, i 17: 1 \omega 7 \mathrm{c}$ and $3-\mathrm{OH} i 17: 0$ appear to be the most useful for the discrimination of Cellulophaga species from other members of the Flavobacteriaceae (Bowman et al., 1998).

\section{Genotypic analysis}

The DNA $\mathrm{G}+\mathrm{C}$ contents of the Antarctic strains (Table 2) ranged from 36 to $38 \mathrm{~mol} \%$ (mean $37 \cdot 1 \pm 0 \cdot 8$, $n=7$ ), as determined by the thermal denaturation procedure. By comparison, the DNA G $+\mathrm{C}$ contents for Cellulophaga species and Cytophaga uliginosa are 32-34 mol\% (Johansen et al., 1999; Reichenbach, 1989) and $42 \mathrm{~mol} \%$ (Reichenbach, 1989), respectively. DNA-DNA hybridization analyses indicated that DNA of strain IC $166^{\mathrm{T}}$ hybridized at high levels to five other Antarctic strains, with values ranging from 81 to $95 \%( \pm 7-16 \%)$ (Table 4$)$. No significant hybridization $(<25 \%$ hybridization) was detected between $\mathrm{IC} 66^{\mathrm{T}}$ and the species Cellulophaga lytica, Cellulophaga baltica, Cellulophaga fucicola, Cytophaga marinoflava, Cytophaga uliginosa or Cytophaga latercula (Table 4). From these results, it can be concluded that the Antarctic agarolytic strains are a distinct genospecies.

\section{S rDNA sequence analysis}

Analysis of previously determined 16S rDNA sequence data (Bowman et al., 1997b) indicated that $\mathrm{IC} 166^{\mathrm{T}}$ was most similar to Cellulophaga baltica LMG $18535^{\mathrm{T}}$. The strains share a sequence similarity of $0 \cdot 97$. IC $166^{\mathrm{T}}$ was comparatively more distant from other Cellulophaga species and from Cytophaga uliginosa, with sequence similarities ranging from 0.91 to 0.92 (Table 4). $16 \mathrm{~S}$ rDNA sequence comparison places strain $\mathrm{IC} 166^{\mathrm{T}}$, the members of the genus Cellulophaga and Cytophaga uliginosa into a single group (Fig. 1). The stability of this group is supported by high bootstrap values (range $81-97 \%)$.

\section{Classification of the Antarctic strains}

The Antarctic strains can be differentiated from the species Cellulophaga baltica by a number of phenotypic traits, including growth temperature range, tolerance of $\mathrm{NaCl}$, range of proteolytic activity and carbohydrate oxidation (Table 2). The DNA G + C content of the Antarctic strains was also 3-5 mol\% higher 
Table 2. Phenotypic characteristics of the Antarctic strains and species of the genus Cellulophaga

The following characteristics were positive for all strains tested: growth on marine 2216 agar and R2A seawater agar; growth at $10-25^{\circ} \mathrm{C}$; hydrolysis of agar, CMC, starch, aesculin, $o$-nitrophenyl $\beta$-galactopyranoside and L-tyrosine; pigment formation on L-tyrosine agar; and acid production from D-glucose, D-galactose, sucrose, trehalose and cellobiose. The following characteristics were negative for all strains tested: formation of filamentous, helical or circular cells; growth on R2A and Anacker-Ordal agar; fermentation of D-glucose; anaerobic growth on marine 2216 agar; nitrate reduction; denitrification; hydrolysis of xanthine and dextran; arginine dihydrolase, lysine decarboxylase, ornithine decarboxylase, tryptophan deaminase, alkaline phosphatase and cytochrome $c$ oxidase activities; Voges-Proskauer test; indole production; and acid production from adonitol, inositol, D-sorbitol and dextran. Abbreviations: + , test positive for $90-100 \%$ of strains; - , test negative for $90-100 \%$ of strains; $\mathrm{V}+$, test positive for $11-89 \%$ of strains and the type strain is positive; $\mathrm{V}-$, test positive for $11-89 \%$ of strains and the type strain is negative. Results in parentheses indicate tests that gave only weak responses.

\begin{tabular}{|c|c|c|c|c|c|}
\hline Characteristic & $\begin{array}{l}\text { Antarctic strains } \\
\quad(n=7)\end{array}$ & $\begin{array}{c}\text { Cellulophaga lytica } \\
\qquad(n=4)\end{array}$ & $\begin{array}{c}\text { Cellulophaga } \\
\text { baltica* }^{*}\end{array}$ & $\begin{array}{c}\text { Cellulophaga fucicola } \\
\text { LMG } 18536^{\mathrm{T} *}\end{array}$ & $\begin{array}{c}\text { Cytophaga } \\
\text { uliginosa } \\
\text { ACAM 538 }\end{array}$ \\
\hline Flexirubin pigment & - & - & - & - & + \\
\hline \multicolumn{6}{|l|}{ Growth on: } \\
\hline Nutrient agar & $(\mathrm{V}+)$ & $(\mathrm{V}-)$ & - & - & - \\
\hline \multirow{2}{*}{\multicolumn{6}{|c|}{ Growth at: }} \\
\hline & & & & & \\
\hline$-2^{\circ} \mathrm{C}$ & + & - & - & - & - \\
\hline $4^{\circ} \mathrm{C}$ & + & - & + & + & $(+)$ \\
\hline $30^{\circ} \mathrm{C}$ & - & + & + & + & + \\
\hline \multicolumn{6}{|l|}{ Hydrolysis of: } \\
\hline Gelatin & + & $\mathrm{V}+$ & + & + & + \\
\hline Chitin & $\mathrm{V}-$ & - & {$[-] \dagger$} & - & + \\
\hline DNA & $\mathrm{V}+$ & - & + & + & + \\
\hline Casein & + & $\mathrm{V}-$ & + & - & + \\
\hline Elastin & - & - & + & + & - \\
\hline Fibrinogen & - & - & + & - & - \\
\hline Tween 80 & + & $\mathrm{V}-$ & {$[+]$} & + & $(+)$ \\
\hline Urate & - & - & {$[+]$} & + & - \\
\hline Lipase activity & $\mathrm{V}-$ & $\mathrm{V}-$ & {$[-]$} & - & - \\
\hline Nitrate reduction & + & - & {$[-]$} & + & + \\
\hline Urease activity & - & - & {$[-]$} & + & - \\
\hline Cytochrome $c$ oxidase activity & + & + & - & - & + \\
\hline \multicolumn{6}{|l|}{ Formation of acid from: } \\
\hline D-Fructose & $\mathrm{V}-$ & + & {$[+]$} & + & + \\
\hline D-Mannose & + & + & {$[+]$} & - & + \\
\hline L-Arabinose & - & $\mathrm{V}-$ & {$[-]$} & + & + \\
\hline D-Xylose & - & $\mathrm{V}-$ & {$[+]$} & - & + \\
\hline$N$-Acetylglucosamine & $\mathrm{V}-$ & - & {$[-]$} & - & + \\
\hline D-Mannitol & - & + & {$[-]$} & - & - \\
\hline Maltose, lactose & + & + & {$[-]$} & - & + \\
\hline Glycerol & - & $\mathrm{V}+$ & {$[-]$} & - & - \\
\hline L-Rhamnose & - & $\mathrm{V}-$ & {$[-]$} & + & - \\
\hline DNA G + C content $(\mathrm{mol} \%)$ & $36-38$ & $32-34$ & 33 & 32 & 42 \\
\hline
\end{tabular}

* Some data are from Johansen et al. (1999).

$\dagger$ Data available only for the type strain of C. baltica $\left(\mathrm{LMG} 18535^{\mathrm{T}}\right)$ are shown in square brackets.

than that of Cellulophaga baltica (Table 2). The Antarctic isolates possess a common relatedness, as indicated by DNA-DNA hybridization values, while a representative strain, $\mathrm{IC} 166^{\mathrm{T}}$, was genetically distinct from other Cellulophaga species (Table 4). The Antarctic isolates thus represent a distinct species within the genus Cellulophaga and the name Cellulophaga algicola sp. nov. is proposed, in recognition of the isolation sites of the species and their presumed epiphytic mode of existence.

\section{Reclassification of Cytophaga uliginosa}

In this study, it is also proposed that Cytophaga uliginosa belongs to the genus Cellulophaga and should be renamed Cellulophaga uliginosa comb. nov. Cyto- 
Table 3. Whole-cell fatty acid profiles of the Antarctic strains and species of the genus Cellulophaga

Fatty acid data are from Bowman et al. (1998) and this study. The values are mean percentages; the values in parentheses are standard deviations. a, anteiso; $i$, iso.

\begin{tabular}{|c|c|c|c|c|c|}
\hline Fatty acid & $\begin{array}{l}\text { Antarctic strains } \\
\quad(n=7)\end{array}$ & $\begin{array}{c}\text { Cellulophaga lytica } \\
\quad(n=4)\end{array}$ & $\begin{array}{c}\text { Cellulophaga baltica } \\
\text { LMG } 18535^{\mathrm{T}}\end{array}$ & $\begin{array}{c}\text { Cellulophaga } \\
\text { fucicola } \text { LMG } 18536\end{array}$ & $\begin{array}{c}\text { Cytophaga } \\
\text { uliginosa ACAM 538 }\end{array}$ \\
\hline $14: 0$ & $0 \cdot 3(0 \cdot 2)$ & $0 \cdot 6(0 \cdot 3)$ & $0 \cdot 8$ & $0 \cdot 5$ & $0 \cdot 8$ \\
\hline$i 15: 1 \omega 10 \mathrm{c}$ & $7 \cdot 5(2 \cdot 0)$ & $10 \cdot 3(1 \cdot 7)$ & $9 \cdot 8$ & $9 \cdot 0$ & $10 \cdot 4$ \\
\hline$a 15: 1 \omega 10 \mathrm{c}$ & $\operatorname{tr}$ & tr & - & $0 \cdot 3$ & - \\
\hline$i 15: 0$ & $7 \cdot 5(1 \cdot 8)$ & $18 \cdot 9(3 \cdot 6)$ & $13 \cdot 6$ & $21 \cdot 4$ & $31 \cdot 3$ \\
\hline$a 15: 0$ & $2 \cdot 5(1 \cdot 0)$ & $1 \cdot 0(0 \cdot 6)$ & $2 \cdot 6$ & $1 \cdot 2$ & $3 \cdot 3$ \\
\hline $15: 1 \omega 6 \mathrm{c}$ & $2 \cdot 6(0 \cdot 6)$ & $2 \cdot 5(0 \cdot 8)$ & $2 \cdot 3$ & $1 \cdot 4$ & $1 \cdot 0$ \\
\hline $15: 0$ & $14 \cdot 3(2 \cdot 4)$ & $9 \cdot 3(2 \cdot 0)$ & $12 \cdot 2$ & $9 \cdot 8$ & $10 \cdot 4$ \\
\hline$i 16: 1 \omega 6 \mathrm{c}$ & $2 \cdot 2(1 \cdot 1)$ & $1 \cdot 4(1 \cdot 0)$ & $1 \cdot 1$ & $1 \cdot 3$ & $0 \cdot 5$ \\
\hline$i 16: 0$ & $2 \cdot 7(1 \cdot 3)$ & $0.9(0 \cdot 3)$ & $0 \cdot 6$ & $1 \cdot 4$ & $0 \cdot 1$ \\
\hline $16: 1 \omega 7 \mathrm{c}$ & $19 \cdot 2(3 \cdot 0)$ & $9 \cdot 0(1 \cdot 5)$ & $16 \cdot 9$ & $13 \cdot 8$ & $11 \cdot 7$ \\
\hline $16: 0$ & $1 \cdot 3(0 \cdot 5)$ & $1 \cdot 7(1 \cdot 0)$ & $3 \cdot 4$ & $1 \cdot 2$ & $6 \cdot 2$ \\
\hline$i 17: 1 \omega 7 \mathrm{c}$ & $6 \cdot 1(1 \cdot 5)$ & $5 \cdot 1(0 \cdot 9)$ & $5 \cdot 2$ & $6 \cdot 7$ & $6 \cdot 2$ \\
\hline$a 17: 1 \omega 7 \mathrm{c}$ & $0 \cdot 7(0 \cdot 3)$ & $1 \cdot 5(0 \cdot 5)$ & $0 \cdot 9$ & $1 \cdot 0$ & $0 \cdot 5$ \\
\hline$i 17: 0$ & $\operatorname{tr}$ & $0 \cdot 1(0 \cdot 1)$ & $0 \cdot 3$ & $0 \cdot 3$ & $0 \cdot 9$ \\
\hline $17: 1 \omega 6 \mathrm{c}$ & - & $0 \cdot 1(0 \cdot 1)$ & $0 \cdot 2$ & $\operatorname{tr}$ & $0 \cdot 6$ \\
\hline $3-\mathrm{OH} i 15: 0$ & $8 \cdot 6(2 \cdot 3)$ & $6 \cdot 2(1.9)$ & $6 \cdot 1$ & $3 \cdot 2$ & $0 \cdot 8$ \\
\hline $3-\mathrm{OH}$ a15:0 & $1 \cdot 5(1 \cdot 0)$ & $1 \cdot 1(0 \cdot 7)$ & $0 \cdot 4$ & $1 \cdot 8$ & $1 \cdot 0$ \\
\hline 3-OH 15:0 & $0 \cdot 7(0 \cdot 5)$ & $0 \cdot 3(0 \cdot 2)$ & $0 \cdot 1$ & $\operatorname{tr}$ & - \\
\hline $3-\mathrm{OH} i 16: 0$ & $6.5(1.9)$ & $5 \cdot 2(3 \cdot 4)$ & $7 \cdot 3$ & $5 \cdot 0$ & $6 \cdot 1$ \\
\hline 3-OH 16:0 & $1 \cdot 8(0 \cdot 9)$ & $0 \cdot 3(0 \cdot 3)$ & $1 \cdot 1$ & $1 \cdot 9$ & $2 \cdot 1$ \\
\hline $3-\mathrm{OH} i 17: 0$ & $4 \cdot 5(2 \cdot 0)$ & $20 \cdot 8(4 \cdot 0)$ & $14 \cdot 0$ & $16 \cdot 9$ & $11 \cdot 7$ \\
\hline $3-\mathrm{OH}$ a17:0 & $0 \cdot 9(0 \cdot 6)$ & $0 \cdot 2(0 \cdot 2)$ & $0 \cdot 3$ & $0 \cdot 2$ & $0 \cdot 4$ \\
\hline Other & $1 \cdot 3(0 \cdot 5)$ & $1.5(0.8)$ & $0 \cdot 8$ & $1 \cdot 7$ & $0 \cdot 9$ \\
\hline
\end{tabular}

tr, Trace fatty acid, present at $0 \cdot 1 \%$ or less of total fatty acid.

Table 4. DNA-DNA hybridization between the Antarctic strains, Cellulophaga species and other related species

DNA-DNA hybridization and $16 \mathrm{~S}$ rDNA sequence similarity are shown relative to strain IC166 ${ }^{\mathrm{T}}$.

\begin{tabular}{|lcc|}
\hline Strain & $\begin{array}{c}\text { DNA-DNA hybridization } \\
(\mathbf{\%})\end{array}$ & $\begin{array}{c}\text { 16S rDNA sequence } \\
\text { similarity }\end{array}$ \\
\hline IC166 $^{\mathrm{T}}$ & 100 & $1 \cdot 00$ \\
IC155 & 95 & - \\
IC156 & 90 & - \\
IC167 & 81 & - \\
IC137 & 92 & $0 \cdot 97$ \\
Cellulophaga baltica LMG $18535^{\mathrm{T}}$ & 30 & $0 \cdot 91$ \\
Cellulophaga lytica ACAM $74^{\mathrm{T}}$ & 21 & $0 \cdot 92$ \\
Cellulophaga fucicola LMG $18536^{\mathrm{T}}$ & 19 & $0 \cdot 91$ \\
Cytophaga uliginosa ACAM $538^{\mathrm{T}}$ & 18 & $0 \cdot 88$ \\
Cytophaga marinoflava ACAM 75 $75^{\mathrm{T}}$ & 12 & $0 \cdot 89$ \\
Cytophaga latercula ATCC $23177^{\mathrm{T}}$ & 20 & \\
\hline
\end{tabular}

phaga uliginosa was originally isolated by ZoBell \& Upham (1944) and initially called 'Agarbacterium uliginosum', until Weeks (1974) transferred it into the genus Flavobacterium. Subsequently, the species was transferred to the genus Cytophaga by Reichenbach (1989). The genus Cytophaga is now made up of only 


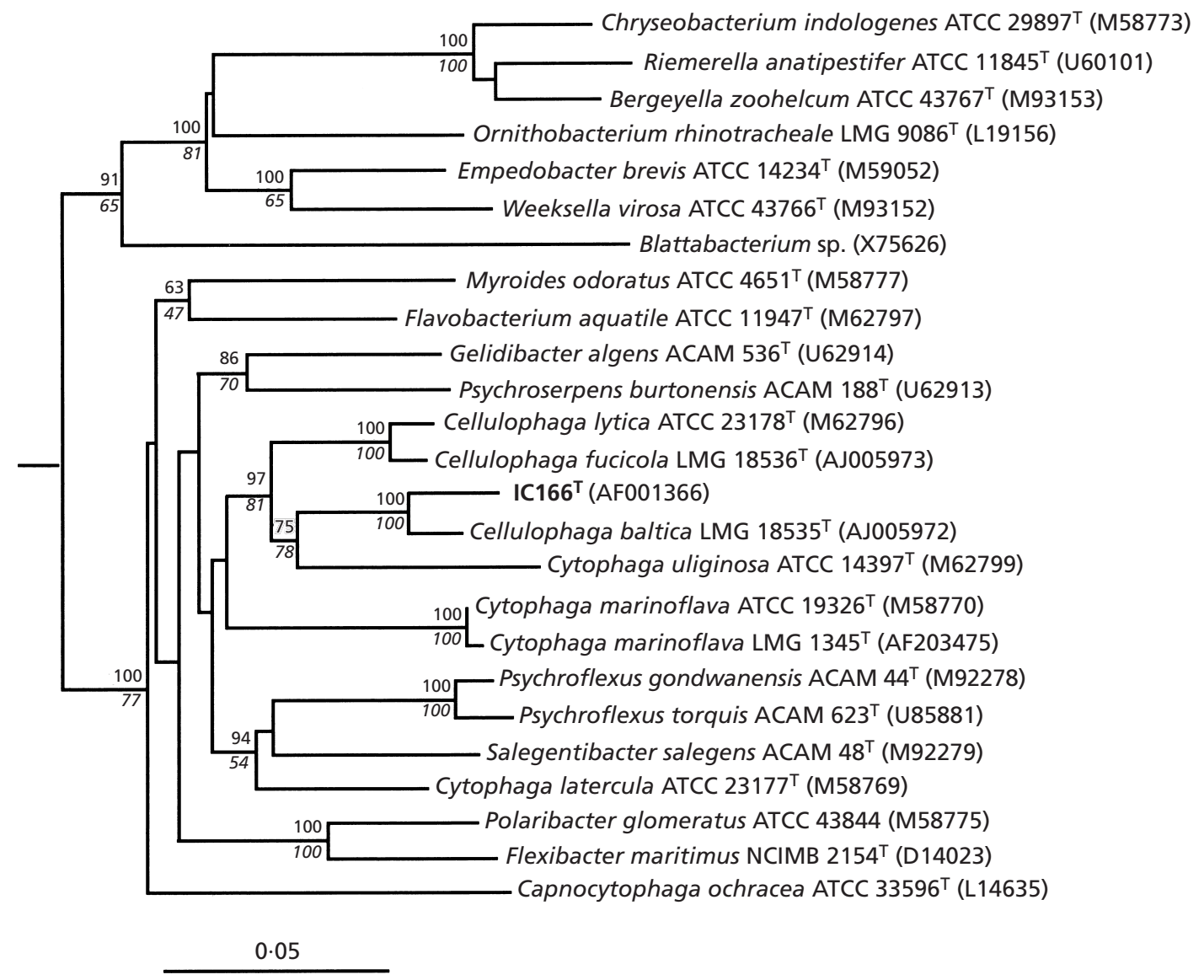

Fig. 1. Phylogenetic tree based on $16 \mathrm{~S}$ rRNA gene sequences, depicting species of the family Flavobacteriaceae including IC $166^{\top}$ and the species of the genus Cellulophaga. The numbers at the branch points are bootstrap values (only those $>$ $60 \%$ are shown), with the values above the line calculated by the maximum-likelihood/neighbour-joining methods while the values below the line were calculated by maximum-parsimony analysis.

two species, Cytophaga hutchinsonii and Cytophaga aurantiaca, which are remote from Cytophaga uliginosa in terms of $16 \mathrm{~S}$ rDNA sequences (Nakagawa \& Yamasoto, 1996). 16S rDNA sequence analyses instead indicate that Cellulophag a species and Cytophaga uliginosa form a common group (Fig. 1). In addition, Cytophaga uliginosa possesses phenotypic characteristics and fatty acids similar to those of other Cellulophaga species (Tables 2 and 3). A number of characteristics, including the ability to form flexirubin pigments and a relatively high $\mathrm{G}+\mathrm{C}$ content, are useful for the differentiation of the species from other Cellulophaga species (Table 2).

\section{Description of Cellulophaga algicola sp. nov.}

Cellulophaga algicola (al.gi.co'la. M.L. n. algae algae; L. n. incola inhabitant, dweller; M.L. fem. n. algicola algae-dweller).

Cells are rod-shaped with either rounded or tapered ends and with cells lengths and widths ranging from 1.5 to 4 and 0.4 to $0.5 \mu \mathrm{m}$, respectively. Gliding motility present. Colonies on marine 2216 agar have yelloworange pigmentation and a compact centre, with a spreading edge possessing lighter pigmentation, are slimy in consistency and are slightly sunken into the agar. Flexirubin pigments are not formed. Agar around and beneath colonies is softened but not liquefied. Strictly aerobic chemoheterotroph. Does not require elevated $\mathrm{CO}_{2}$ levels for growth. Strains grow between 0.5 and $10 \% \mathrm{NaCl}$, with best growth in the presence of about $2 \% \mathrm{NaCl}$. Growth on nutrient agar is poor, while no growth occurs on R2A or AnackerOrdal agar. Grows between -2 and $28^{\circ} \mathrm{C}$, with mostrapid growth at about $15-20^{\circ} \mathrm{C}$ on agar media and at about $20-25^{\circ} \mathrm{C}$ in liquid media. Optimal $\mathrm{pH}$ for growth is about 7.5. Can hydrolyse agar, starch, CMC, casein, Tween 80, tributyrin and L-tyrosine but not urate, xanthine or dextran. Forms a reddish-brown diffusible pigment when grown in the presence of $1 \%$ L-tyrosine. Nitrate reduction, denitrification, $\mathrm{H}_{2} \mathrm{~S}$ production and indole production are negative. Acid is formed oxidatively from D-galactose, D-glucose, Dfructose, sucrose, cellobiose, lactose and mannitol. Other characteristics are shown in Table 2. G+C 
content of the DNA ranges from 36 to $38 \mathrm{~mol} \%$ ( $T_{\mathrm{m}}$ method). Isolated from the surfaces of algal species from the Antarctic marine coast and sea ice. The type strain is $\operatorname{IC} 166^{\mathrm{T}}\left(=\mathrm{ACAM} 630^{\mathrm{T}}\right)$.

\section{Description of Cellulophaga uliginosa comb. nov. ('Agarbacterium uliginosum' (ZoBell and Upham 1944) Breed 1957; Flavobacterium uliginosum (ZoBell and Upham) Weeks 1974; Cytophaga uliginosa (ZoBell and Upham 1944) Reichenbach 1989)}

The species Cellulophaga uliginosa was described as Cytophaga uliginosa by Reichenbach (1989). Starch hydrolysis was listed as negative in the original description; however, it was listed as positive in Table 23.2 of Reichenbach (1989). It was confirmed in this study that the strain actively degrades starch. The description of the species is otherwise the same as that given previously. In addition, the strain grows between 1 and $4 \% \mathrm{NaCl}$ and between 4 and $35^{\circ} \mathrm{C}$. CMC is hydrolysed slowly. Extracellular deoxyribonucleases are formed. Acid is formed oxidatively from D-xylose, D-galactose, D-glucose, D-fructose, D-mannose, trehalose, maltose, sucrose, cellobiose, lactose and $\mathrm{N}$ acetylglucosamine. Acid is not formed from L-rhamnose, adonitol, glycerol, inositol, D-mannitol, D-sorbitol or dextran. Only a single strain is known, and was isolated from surface sediment by ZoBell \& Upham (1944). The type strain is ACAM $538^{\mathrm{T}}$ (= ATCC $14397^{\mathrm{T}}=\mathrm{NCIMB} \quad 1863^{\mathrm{T}}=\mathrm{DSM} \quad 2061^{\mathrm{T}}=$ CECT $4277^{\mathrm{T}}=$ CIP $\left.104808^{\mathrm{T}}\right)$.

\section{ACKNOWLEDGEMENTS}

This study was supported by grants from the Australian Research Council and from the Antarctic Science Advisory Committee. I would like to thank Jenny Skerratt and Sharee McCammon for technical assistance.

\section{REFERENCES}

Bernardet, J.-F., Segers, P., Vancanneyt, M., Berthe, F., Kersters, K. \& Vandamme, P. (1996). Cutting a Gordian knot: emended classification and description of the genus Flavobacterium, emended description of the family Flavobacteriaceae, and proposal of Flavobacterium hydatis nom. nov. (basonym, Cytophaga aquatilis Strohl and Tait 1978), Int J Syst Bacteriol 46, 128-148.

Bowman, J. P., McCammon, S. A., Brown, J. L., Nichols, P. D. \& McMeekin, T. A. (1997a). Psychroserpens burtonensis gen. nov., sp. nov., and Gelidibacter algens gen. nov., sp. nov., psychrophilic bacteria isolated from Antarctic lacustrine and sea ice habitats, Int J Syst Bacteriol 47, 670-677.

Bowman, J. P., McCammon, S. A., Brown, M. V., Nichols, D. S. \& McMeekin, T. A. (1997b). Diversity and association of psychrophilic bacteria in Antarctic sea ice, Appl Environ Microbiol 63, 3068-3078.

Bowman, J. P., McCammon, S. A., Lewis, T., Skerratt, J. H., Brown, J. L., Nichols, D. S. \& McMeekin, T. A. (1998). Psychroflexus torquis gen. nov. sp. nov., a psychrophilic species from Antarctic sea ice, and reclassification of Flavobacterium gondwanense (Dobson et al. 1993) as Psychroflexus gondwanense gen. nov., comb. nov, Microbiology 144, 1601-1609.

Fautz, E. \& Reichenbach, H. (1980). A simple test for flexirubintype pigments, FEMS Microbiol Lett 8, 87-91.

Felsenstein, J. (1993). PHYLIP (phylogeny inference package), version 3.57c. University of Washington, Seattle, WA, USA.

Glöckner, F. O., Fuchs, B. M. \& Amann, R. (1999). Bacterioplankton compositions of lakes and oceans: a first comparison based on fluorescence in situ hybridization, Appl Environ Microbiol 65, 3721-3726.

Gosink, J. J., Woese, C. R. \& Staley, J. T. (1998). Polaribacter gen. nov., with three new species, $P$. irgensii sp. nov., $P$. franzmannii sp. nov. and $P$. filamentus sp. nov., gas vacuolate polar marine bacteria of the Cytophaga-Flavobacterium-Bacteroides group and reclassification of 'Flectobacillus glomeratus' as Polaribacter glomeratus comb. nov, Int J Syst Bacteriol 48, 223-235.

Gutell, R. R. (1994). Collection of small subunit (16S and 16Slike) ribosomal RNA structures: 1994, Nucleic Acids Res 22, 3502-3507.

Huss, V. A. R., Festl, H. \& Schleifer, K. H. (1983). Studies on the spectrophotometric determination of DNA hybridisation from renaturation rates, Syst Appl Microbiol 4, 184-192.

Johansen, J. E., Nielsen, P. \& Sjøholm, C. (1999). Description of Cellulophaga baltica gen. nov., sp. nov. and Cellulophaga fucicola gen. nov., sp. nov. and reclassification of [Cytophaga] lytica to Cellulophaga lytica gen. nov., comb. nov, Int J Syst Bacteriol 49, 1231-1240.

Kouker, G. \& Jaeger, K.-E. (1987). Specific and sensitive plate assay for bacterial lipases, Appl Environ Microbiol 53, 211-213.

Leifson, E. (1963). Determination of carbohydrate metabolism of marine bacteria, J Bacteriol 85, 1183-1184.

McCammon, S. A. \& Bowman, J. P. (2000). Taxonomy of Antarctic Flavobacterium species: description of Flavobacterium gillisiae sp. nov., Flavobacterium tegetincola sp. nov. and Flavobacterium xanthum sp. nov., nom. rev. and reclassification of [Flavobacterium] salegens as Salegentibacter salegens gen. nov., comb. nov, Int J Syst Evol Microbiol 50, 1055-1063.

McCammon, S. A., Innes, B. H., Bowman, J. P., Franzmann, P. D., Dobson, S. J., Holloway, P. E., Skerratt, J. H., Nichols, P. D. \& Rankin, L. M. (1998). Flavobacterium hibernum sp. nov., a lactose-utilizing bacterium from a freshwater Antarctic lake, Int J Syst Bacteriol 48, 1405-1412.

Marmur, J. \& Doty, P. (1962). Determination of the base composition of deoxyribonucleic acid from its thermal denaturation temperature, J Mol Biol 5, 109-118.

Nakagawa, Y. \& Yamasato, K. (1996). Emendation of the genus Cytophaga and transfer of Cytophaga agarovorans and Cytophaga salmonicolor to Marinilabilia gen. nov.: phylogenetic analysis of the Flavobacterium-Cytophaga complex, Int J Syst Bacteriol 46, 599-603.

Nichols, P. D., Guckert, J. B. \& White, D. C. (1986). Determination of monounsaturated fatty acid double-bond position and geometry for microbial monocultures and complex consortia by capillary GC-MS of their dimethyldisulphide adducts, $J$ Microbiol Methods 5, 49-55.

Reichenbach, H. (1989). Genus I. Cytophaga Winogradsky 1929, 577, ${ }^{\mathrm{AL}}$ emend. In Bergey's Manual of Systematic Bacteriology, vol. 3, pp. 2015-2050. Edited by J. T. Staley, M. P. Bryant, N. Pfennig \& J. G. Holt. Baltimore: Williams \& Wilkins.

Sly, L. I., Blackall, L. L., Kraat, P. C., Tian-Shen, T. \& Sangkhobol, V. 
(1986). The use of second derivative plots for the determination of mol\% guanine plus cytosine of DNA by the thermal denaturation method, J Microbiol Methods 5, 139-156.

Weeks, O. B. (1974). Genus Flavobacterium Bergey et al., 1923, 97. In Bergey's Manual of Determinative Bacteriology, 8th edn,, pp. 357-364. Edited by R. E. Buchanan \& N. E. Gibbons. Baltimore: Williams \& Wilkins.

ZoBell, C. E. \& Upham, H. C. (1944). A list of marine bacteria including descriptions of sixty new species, Bull Scripps Inst Oceanogr Univ Calif 5, 239-292. 